\author{
Asian Journal of \\ Medical and Biological Research \\ ISSN 2411-4472 (Print) 2412-5571 (Online) \\ www.ebupress.com/journal/ajmbr
}

\title{
Article \\ Effects of breed, age, parity, body weight and body condition on productive and reproductive performance of buffalo cows at Rajshahi district of Bangladesh
}

\author{
Rashida Khaton $^{1}$, Md. Zakir Hossain ${ }^{1}$, Md. Reazul Islam ${ }^{2}$ and Md. Jalal Uddin Sarder ${ }^{1}$ \\ ${ }^{1}$ Department of Veterinary and Animal Sciences, University of Rajshahi, Rajshahi-6205, Bangladesh \\ ${ }^{2}$ Department of Preclinical Courses, Faculty of Veterinary and Animal Sciences, Gono Bishwabidyalay, Savar, \\ Dhaka-1344, Bangladesh
}

*Corresponding Author: Veterinary and Animal Sciences Department, Faculty of Agriculture, University of Rajshahi, Rajshahi-6205, Bangladesh. Phone: +88-0721-711141(office). E-mail: rashidavet@yahoo.com

Received: 03 September 2020/Accepted: 26 September 2020/ Published: 30 September 2020

\begin{abstract}
The present study was to evaluate the reproductive and productive performance (RPP) of Indigenous $(n=145)$ and Nili-Ravi cross-bred $(n=55)$ dairy buffalo in relation to age, parity, body weight and body condition. A total of 200 buffalo cows were randomly selected and interviewed to collect data on reproductive and productive performance of buffalo cows of Rajshahi district by using pre-tested questionnaire during the period from January 2015 to December 2015. The average mean \pm SD value of reproductive and productive performances were as age at puberty (AP), age at first calving (AFC), gestation length (GL), post-partum heat period (PPHP), milk yield per day (MYPD), lactation length (LL), birth weight of calf (BWC) and calving interval (CI) were recorded as $25.05 \pm 4.00$ months, $35.26 \pm 4.14$ months, $308.28 \pm 12.46$ days, $84.00 \pm 25.95$ days, $3.59 \pm 0.56$ litre, $202.76 \pm 33.54$ days, $28.79 \pm 4.23$ kilogram and $461.36 \pm 15.41$ days, respectively. Nili-Ravi crossbred buffalo cow had shown better RPP than Indigenous. The genotype of buffalo cows had significant effect $(\mathrm{p}<0.05)$ on most of the RPP except AP, AFC and CI. Age of buffalo had also significant effect $(\mathrm{p}<0.05)$ on GL, PPHP and BWC and middle age ( 4 to $<7 y$ rs) observed good RPP. The best RPP were recorded in $2^{\text {nd }}$ parity than others and also significant effect $(\mathrm{p}<0.05)$ on GL, MYPD and BWC. Body weight and body condition of buffalo had significant effect $(\mathrm{p}<0.05)$ on PPHP, BWC and MYPD. The body weight of $>350 \mathrm{~kg}$ and very good body condition groups were observed better reproductive performance. It could be concluded that the buffalo owners of these areas do not follow any scientific method of buffalo husbandry; they just follow traditional rearing systems. Very recently, a few farmers started farming of the mostly Indigenous buffalo cows for dairy purpose at Rajshahi region of Bangladesh.
\end{abstract}

Keywords: effects; breed; age; parity; body weight; body condition; Buffalo cows; Rajshahi district

\section{Introduction}

Buffalo cow rearing is one of the most important occupations. The success of any dairy farm depends upon efficient productive and reproductive performances of a dairy animal. Different genetic and non-genetic factors influence its performance potential (Boro et al., 2020). Productive performance is determined to a great extent by the milk yield at first lactation and the farm, followed by the age at first calving (Ilieva and Peeva, 2007). The importance of livestock production has increased in Bangladesh as witnessed by the growth of the subsector over the last few decades in Bangladesh (FAO, 2005). The buffalo hold strategic place in overall livestock economy of Bangladesh and serve three important purposes viz. milk production, meat and draught power (Ghaffar et al., 1991). Cattle and buffalo supplies about $99 \%$ of the total milk produced in the country, $50.2 \%$ of the total milk consumes and $98 \%$ of the draught power requirement of the country. Contribution of cattle to national economy is not static rather varies depending upon population size and location. The domestic buffalo is an important animal in the agricultural economy of many tropical and subtropical countries and being an integral part of farming system (Suhail et al., 2009). Buffalo is contributing $12.1 \%$ to the world, $38.0 \%$ in 
Asia, 66.6\% in Pakistan, 55.0\% in India, 16.4\% in China, 50.8\% in Egypt and 65.2\% in Nepal's total milk production (FAO, 2007). In addition to the milk buffalo is also used as an important source of beef production in the form of culled adult females, males and unwanted male calves. Buffalo is contributing around 1.3, 2.8, 24.4, 26.9, 0.6, 21.2, and 51.8\% of the total meat production in the aforementioned countries (Suhail et al., 2009). Buffalo have significant contribution in GDP through production of meat, milk and skin representing about $27.0 \%, 23.0 \%$ and $28.0 \%$, respectively to the total production from livestock sector (FAO, 2009) in Bangladesh. According to the estimate of Bangladesh Economic Review (2009), the current buffalo population in Bangladesh is about 1.3 million. Of the total buffalo population of the country $42.8 \%, 39.9 \%$ and $11.8 \%$ buffaloes are found in the sugarcane belt, coastal areas and marshy land, respectively (Faruque et al., 1990).

Buffalo have a number of advantages over cattle viz. utilization of low quality roughages to produce more protein and to gain more body weight, more resistance to common diseases, outstanding draught power, faster body growth and longer life span. A pair of buffalo has more draught capacity than a pair of cattle (Faruque et al., 1990; Rahman, 1991). Generally Indigenous buffalo cows produces more milk than Indigenous cows having more milk fat $(10.5 \%)$ and total solid $(21 \%)$. Another notable advantage specially is that they can survive against tidal wave which they are to encounter now and then. Khan et al. (2008) investigated the postconception decline in milk yield and reported that dairy buffalo in parity 3 had the least reduction in milk yield followed by parity $2,4,1,5$, and 6 , indicating parity 3 as the best phase for milk production in dairy buffaloes. Bashir et al. (2007) reported that economic returns from dairy buffaloes depend on lifetime performance. Herd life and productive life were also used to describe lifetime performance. Husbandry and production systems for buffaloes vary depending on the topography and vegetation patterns of the country. Buffaloes are raised under an extensive system in the coastal and hilly areas where large-scale pasture land and enough green forage are available. There are several published reports regarding reproductive and productive parameters and management system of buffalo cows throughout the world (Hadi, 1965; EI-Kirabi, 1995 and Suhail et al., 2009) but there is very limited information of this issue in contest of Bangladesh especially in Rajshahi areas.

Few scientific works have been done by Faruque and Amin $(1994 ; 1995)$ on limited buffaloes in specific region. But limited scientific research had taken place upon the indigenous buffalo of this region. So, the author showed the greatest interest to obtain some basic reproductive characteristics about the buffalo cows at Rajshahi district for its appropriate description. Despite their important role in national economy and their outstanding production potentials, buffaloes are most neglected in Bangladesh. They are often called non descriptive types (Cockril, 1974). Very little is known about the extent of productive and reproductive performances in buffalo cows in Rajshahi district of Bangladesh. Keeping the facts and ideas in mind, the present study was undertaken to meet up the effect of breed, age, parity, body weight and body condition of buffalo cows on reproductive and productive performance of Rajshahi district of Bangladesh.

\section{Materials and Methods}

\subsection{Study areas and population}

To conduct the study at the districts of Bangladesh namely Rajshahi was selected. Two hundred (200) buffalo cows were randomly selected to collect data regarding reproductive and productive performance of those buffalo cows with separate questionnaires during the period from January 2015 to December 2015.

\subsection{Selection of Animals}

Different breeds of buffalo cows from different places upto 6 parities an absolutely for dairy and drought purpose was considered and selected for the present study. A total 200 buffalo cow were selected from greater Rajshahi district (Kakonhat, Nawhata, Kasiadanga, Damkura, Puthiapara, Godagari, Rajabari, Courtstation and Rajshahi city) in Bangladesh.

\subsection{Method of data collection}

A questionnaire was developed for proper recording the reproductive and productive performance of buffalo cows. The data were collected directly from the buffalo cow owners/farmers/attendant who was responsible for the rearing of buffalo cows. During data collection careful attention was given to attained accurate and reliability of data during the period from January 2015 to December 2015. The data were collected from the randomly selected areas by the researcher every three (3) months interval in year. After collecting the information, data were prepared for analysis. 


\subsection{Grouping of experimental animals}

To achieve the goal, animals were grouped according to the following considering factors:

Genotype or Breed: The buffalo cows were classified broadly in Indigenous and Nili-Ravi cross.

Group I: Indigenous ( $\mathrm{n}=145)$

Group II: Nili-Ravi cross ( $\mathrm{n}=55)$

Age group: Age of the buffalo cows were measured by examination of teeth and counting number of horn ring and birth record kept by the farmers/register book. After confirmation of age of these buffalo cows then divided in the following groups:

Group I: $<4$ yrs $(\mathrm{n}=53)$

N Group II: 4 to $<7 \mathrm{yrs}(\mathrm{n}=118)$

Group III: $>7 \mathrm{yrs}(\mathrm{n}=29)$

Parity: The buffalo cows those did not give any calf considered as heifer $\left(\mathrm{P}_{0}\right)$, those gave $1^{\text {st }}$ calf considered as parity $1\left(\mathrm{P}_{1}\right)$, those gave $2^{\text {nd }}$ calf considered as parity $2\left(\mathrm{P}_{2}\right)$, those gave $3^{\text {rd }}$ calf considered as parity $3\left(\mathrm{P}_{3}\right)$ and so on. The buffalo cows were divided in the following groups:

Group I: $1^{\text {st }}$ calving $(\mathrm{n}=52)$

Group II: $2^{\text {nd }}$ calving $(\mathrm{n}=93)$

Group III: $>3^{\text {rd }}$ calving $(\mathrm{n}=55)$

Body Weight: The body weight of each buffalo cow was recorded in $\mathrm{kg}$ and the body weight was measured by means of a measuring tape applying the formula of Rahman et al. (2004).

Live body weight $=\frac{\mathrm{L} \times \mathrm{G} 2}{300}$ pounds

Where, $\mathrm{L}=$ Length from the point of shoulder to pin bone in inches

$\mathrm{G}=$ Chest girth in inches

Then, the body weights were converted from pound to $\mathrm{kg}$, dividing by 2.2

The selected cows were classified according to their body weight such as

Group I: $<250 \mathrm{~kg}(\mathrm{n}=63)$

Group II: 250 - $350 \mathrm{~kg}(\mathrm{n}=127)$

Group III: > $350 \mathrm{~kg}(\mathrm{n}=10)$

Body condition: Buffalo cows of different body condition were considered for the study and BCS were determined by Nicholson and Butterworth (1986) with some modified technique. The buffalo cows were divided in the following groups considering body conditions:

Group I: Poor $(\mathrm{n}=32)$

Group II: Medium ( $\mathrm{n}=95)$

Group III: Good (n=73)

\subsection{Reproductive and productive traits of buffalo cows studied}

The following reproductive and productive traits of buffalo cows were studied in this study.

Age at puberty: The age at which a heifer first shows estrus sign and behavior may be defined as age at puberty (Hafez, 1993). It measured in month (m) and total number of observation was 200.

Age at first calving: The actual age of buffalo at the time of its first calving. It is defined as the age when a buffalo heifer first calving a newborn calf. It measured in month $(\mathrm{m})$

Gestation length: It is defined as the period between fertilization and birth or the period during which an embryo develops. It is calculated in days (d).

Post partum heat period: It is considered as the interval between date of calving and the date of first insemination or first heat show after parturition. It was calculated in days (d).

Calving interval: It is the period between two successive calving i.e. the period between the calving of the first calf to the calving of immediate next calf and was expressed in days.

Average daily milk yield: It refers to the average milk yield of buffalo during the lactation. This was measured in litre/day by using the following formula:

Average milk yield (lit./day)= Lactation yield/205 days 
Lactation length: It is the number of days a buffalo remain in milk from the date of calving to the date of dry. It express in days or months:

Birth weight of calf: It is defined as the weight of calf during the period of birth. It is calculate in kilogram $(\mathrm{kg})$.

\subsection{Data management and analysis}

The data obtained from the questionnaire was entered into the Microsoft Excel 2007 and transferred to SPSS version, 17.0. Data were statistically analyzed to calculate the effect of reproductive and productive traits of buffalo cows. Various standard statistical procedures had been adopted in the study. The standard error of mean for the reproductive traits was calculated with help of a computer package programme (SPSS) version 17.0. Mean of different traits were then tested by using analysis of Variance (ANOVA) by Duncan Multiple Range Test (DMRT). Data were presented as Mean \pm SE. $\mathrm{P}<0.05$ was considered as significant. Simple ANOVA was performed considering the age of buffalo cows and to observe the significant differences among the mean values, Duncan's multiple range test (DMRT) was performed to observer significant differences of reproductive traits in different genotype, age, parity, body weight, body condition of buffalo cows.

\section{Results}

\subsection{The reproductive and productive performance of buffalo cows in Rajshahi district}

The average mean \pm SD value of reproductive and productive performance such as age at puberty $(\mathrm{m})$, age at first calving (m), gestation length (d), post partum heat period (d), milk yield per day (d) and lactation length (d) were $25.05 \pm 4.00,35.26 \pm 4.14,308.28 \pm 12.46,84.00 \pm 25.95,3.59 \pm 0.56$ and $202.76 \pm 33.54$, respectively (Figure $1)$.

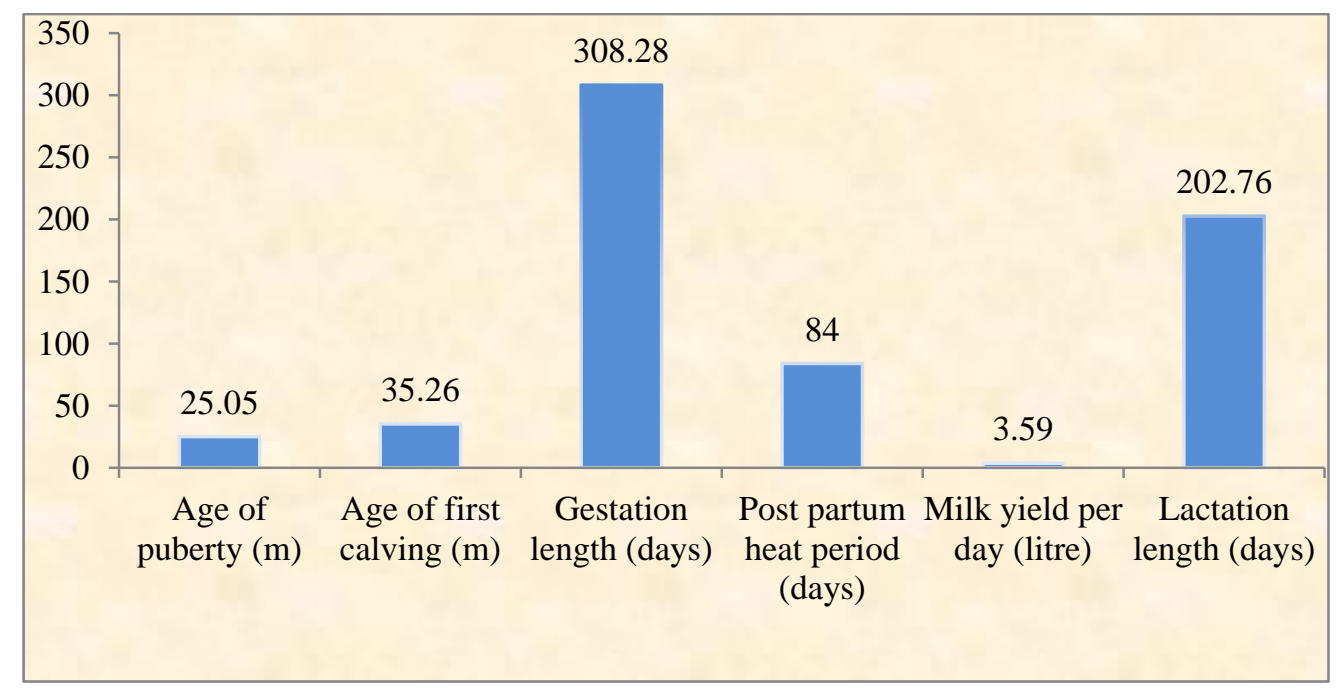

Figure 1. Graphical representation of reproductive and productive values.

\subsection{Effects of genotypes on reproductive and productive performance of buffalo cows}

The effects of genotype on reproductive and productive performance of buffalo cows are summarized in Table 1 and Figure 2. The higher value of age at puberty, age at first calving, gestation length and post-partum heat period $(25.41 \pm 5.86,35.83 \pm 5.57,312.75 \pm 10.74$ and $116.25 \pm 14.63$ were observed in Indigenous buffalo cows and lower value of $(25.02 \pm 3.87,35.22 \pm 4.04,307.99 \pm 12.53$ and $81.91 \pm 25.15$ were observed in Nili-Ravi Cross buffalo cows. The higher value of milk yield per days, lactation length, birth weight of calf and calving interval $(3.60 \pm 0.56,221.67 \pm 33.25,30.00 \pm 5.22$ and $465.83 \pm 17.50)$ were observed in Nili-Ravi Cross buffalo cows and lower value of $(3.37 \pm 0.48,201.55 \pm 33.28,28.71 \pm 4.17$ and $362.29 \pm 15.36)$ were observed in Indigenous buffalo cows. There was significant effect $(\mathrm{P}<0.05)$ of breeds on gestation length, post partum heat period, milk yield per day, lactation length and birth weight of calf. Other reproductive traits were not significant $(\mathrm{P}>0.05)$. 
Table 1. Effects of genotype on reproductive and productive performance of buffalo cows.

\begin{tabular}{|l|l|l|l|}
\hline \multirow{2}{*}{$\begin{array}{l}\text { Reproductive and Productive } \\
\text { performances }\end{array}$} & \multicolumn{2}{|c|}{ Genotype } & \multirow{2}{*}{ Average Value } \\
\cline { 2 - 3 } & Indigenous & Nili-Ravi Cross & \\
\hline Age at puberty (m) & $25.41 \pm 5.86$ & $25.02 \pm 3.87$ & $25.05 \pm 4.00$ \\
& $\mathrm{~N}=145$ & $\mathrm{~N}=55$ & $\mathrm{~N}=200$ \\
\hline Age at first calving (m) & $35.83 \pm 5.57$ & $35.22 \pm 4.04$ & $35.26 \pm 4.14$ \\
& $\mathrm{~N}=145$ & $\mathrm{~N}=55$ & $\mathrm{~N}=200$ \\
\hline Gestation length (days) & $312.75 \pm 10.74^{\mathrm{a}}$ & $307.99 \pm 12.53^{\mathrm{b}}$ & $308.28 \pm 12.46$ \\
& $\mathrm{~N}=145$ & $\mathrm{~N}=55$ & $\mathrm{~N}=200$ \\
\hline Post partum heat period (days) & $116.25 \pm 14.63^{\mathrm{a}}$ & $81.91 \pm 25.15^{\mathrm{b}}$ & $84.00 \pm 25.95$ \\
& $\mathrm{~N}=145$ & $\mathrm{~N}=55$ & $\mathrm{~N}=200$ \\
\hline Milk yield per day (litre) & $3.37 \pm 0.48^{\mathrm{a}}$ & $3.60 \pm 0.56^{\mathrm{b}}$ & $3.59 \pm 0.56$ \\
& $\mathrm{~N}=145$ & $\mathrm{~N}=55$ & $\mathrm{~N}=200$ \\
\hline Lactation length (days) & $201.55 \pm 33.28^{\mathrm{a}}$ & $221.67 \pm 33.25^{\mathrm{b}}$ & $202.76 \pm 33.54$ \\
& $\mathrm{~N}=145$ & $\mathrm{~N}=55$ & $\mathrm{~N}=200$ \\
\hline Birth weight of calf (kg) & $28.71 \pm 4.17^{\mathrm{a}}$ & $30.00 \pm 5.22^{\mathrm{b}}$ & $28.79 \pm 4.23$ \\
& $\mathrm{~N}=145$ & $\mathrm{~N}=55$ & $\mathrm{~N}=200$ \\
\hline Calving interval (days) & $462.29 \pm 15.36$ & $465.83 \pm 17.50$ & $461.36 \pm 15.41$ \\
& $\mathrm{~N}=145$ & $\mathrm{~N}=55$ & $\mathrm{~N}=200$ \\
\hline
\end{tabular}

$\mathrm{m}=$ months, $\mathrm{kg}=$ kilogram, superscripts $(\mathrm{a}, \mathrm{b})$ in the same column differs significantly with each other $(\mathrm{p}<0.05)$.

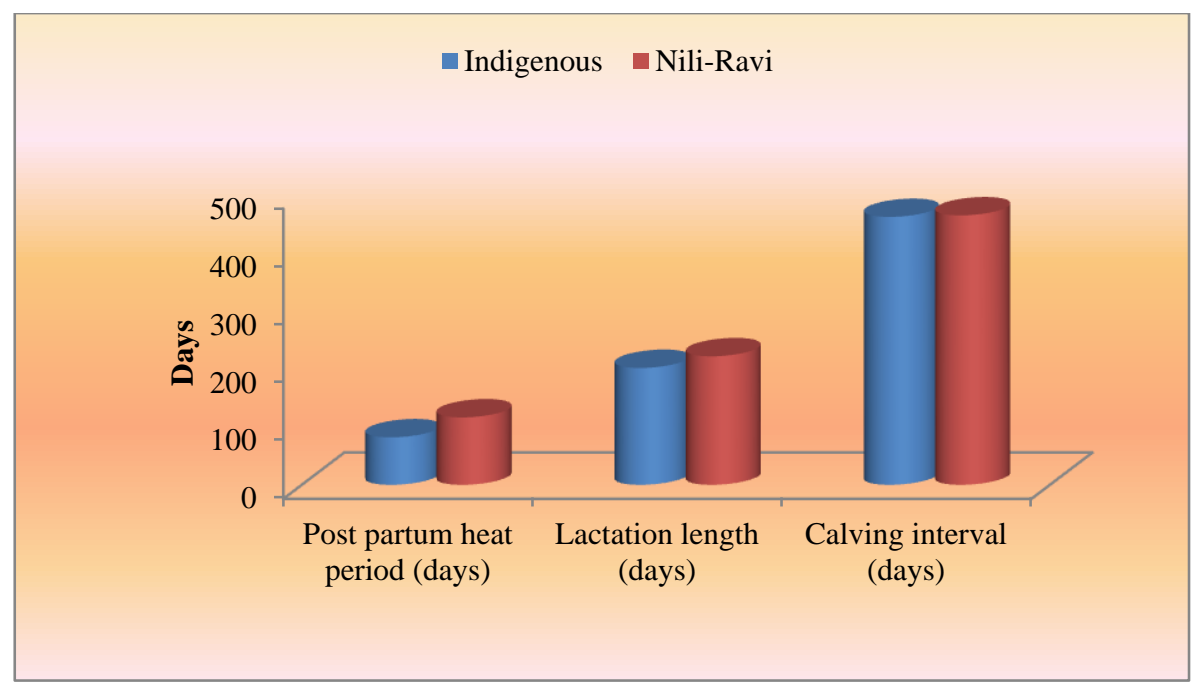

Figure 2. Effect of genotypes of buffalo cows on postpartum heat period, lactation length and calving interval.

\subsection{Effects of age group on reproductive and productive performance of buffalo cows}

The effects of age groups on reproductive and productive performance of buffalo cows are presented in Table 2 and Figure 3. The lower value of age at puberty, age at first calving, gestation length, post partum heat period, lactation length, birth weight of calf and calving interval $(24.09 \pm 2.99,34.47 \pm 3.06,304.08 \pm 8.07,79.05 \pm 21.12$, $202.14 \pm 36.06,27.49 \pm 2.83$ and $459.47 \pm 26.29)$ were observed in $<4$ yrs of age, milk yield per day $(3.43 \pm 0.48)$ was found in $>7 \mathrm{yrs}$ and higher value of age of puberty, age of first calving, milk yield per day and calving interval $(25.56 \pm 4.52,35.77 \pm 4.68,3.63 \pm 0.50$ and $464.43 \pm 37.54)$ were observed in 4 to $<7 y$ rs and higher value of gestation length, post partum heat period, lactation length and birth weight of calf $(307.67 \pm 11.22$, $94.31 \pm 27.34,205.52 \pm 29.22$ and $30.79 \pm 2.7)$ were observed in $>7 \mathrm{yrs}$. Age group had significant $(\mathrm{P}<0.05)$ effect on gestation length, post partum heat period and birth weight of calf and had no significant $(\mathrm{P}>0.05)$ effect on age of puberty, age of first calving, milk yield per day, lactation length and calving interval. 
Table 2. Effects of age groups on reproductive and productive performance of buffalo cows.

\begin{tabular}{|l|l|l|l|l|}
\hline \multirow{2}{*}{$\begin{array}{l}\text { Reproductive and Productive } \\
\text { performances }\end{array}$} & \multicolumn{3}{|c|}{ Age group } & Average Value \\
\cline { 2 - 5 } & $\langle\mathbf{4}$ yrs & $\mathbf{4}$ to $<7 \mathbf{y r s}$ & $>7 \mathbf{y r s}$ & \\
\hline Age at puberty (m) & $24.09 \pm 2.99$ & $25.56 \pm 4.52$ & $24.68 \pm 2.92$ & $25.05 \pm 4.00$ \\
& $\mathrm{~N}=53$ & $\mathrm{~N}=118$ & $\mathrm{~N}=29$ & $\mathrm{~N}=200$ \\
\hline Age at first calving (m) & $34.47 \pm 3.06$ & $35.77 \pm 4.68$ & $34.62 \pm 3.13$ & $35.26 \pm 4.14$ \\
& $\mathrm{~N}=53$ & $\mathrm{~N}=118$ & $\mathrm{~N}=29$ & $\mathrm{~N}=200$ \\
\hline Gestation length (days) & $304.08 \pm 8.07^{\mathrm{b}}$ & $307.67 \pm 11.22^{\mathrm{b}}$ & $318.41 \pm 17.76^{\mathrm{a}}$ & $308.28 \pm 12.46$ \\
& $\mathrm{~N}=53$ & $\mathrm{~N}=118$ & $\mathrm{~N}=29$ & $\mathrm{~N}=200$ \\
\hline Post partum heat period (days) & $79.05 \pm 21.12^{\mathrm{b}}$ & $83.60 \pm 26.97^{\mathrm{b}}$ & $94.31 \pm 27.34^{\mathrm{a}}$ & $84.00 \pm 25.95$ \\
& $\mathrm{~N}=53$ & $\mathrm{~N}=118$ & $\mathrm{~N}=29$ & $\mathrm{~N}=200$ \\
\hline Milk yield per day (litre) & $3.61 \pm 0.59$ & $3.63 \pm 0.50$ & $3.43 \pm 0.48$ & $3.59 \pm 0.56$ \\
& $\mathrm{~N}=53$ & $\mathrm{~N}=118$ & $\mathrm{~N}=29$ & $\mathrm{~N}=200$ \\
\hline Lactation length (days) & $202.14 \pm 36.06$ & $202.64 \pm 30.23$ & $205.52 \pm 29.22$ & $202.76 \pm 33.54 \mathrm{~N}=$ \\
& $\mathrm{N}=53$ & $\mathrm{~N}=118$ & $\mathrm{~N}=29$ & 200 \\
\hline Birth weight of calf (kg) & $27.49 \pm 2.83^{\mathrm{b}}$ & $28.89 \pm 4.8^{\mathrm{b}}$ & $30.79 \pm 2.7^{\mathrm{a}}$ & $28.79 \pm 4.23$ \\
& $\mathrm{~N}=53$ & $\mathrm{~N}=118$ & $\mathrm{~N}=29$ & $\mathrm{~N}=200$ \\
\hline Calving interval (days) & $459.47 \pm 26.29$ & $464.43 \pm 37.54$ & $463.45 \pm 33.01$ & $461.36 \pm 20.41$ \\
& $\mathrm{~N}=53$ & $\mathrm{~N}=118$ & $\mathrm{~N}=29$ & $\mathrm{~N}=200$ \\
\hline
\end{tabular}

$\mathrm{m}=$ months, $\mathrm{kg}=$ kilogram, superscripts $(\mathrm{a}, \mathrm{b})$ in the same column differs significantly with each other $(\mathrm{p}<0.05)$.

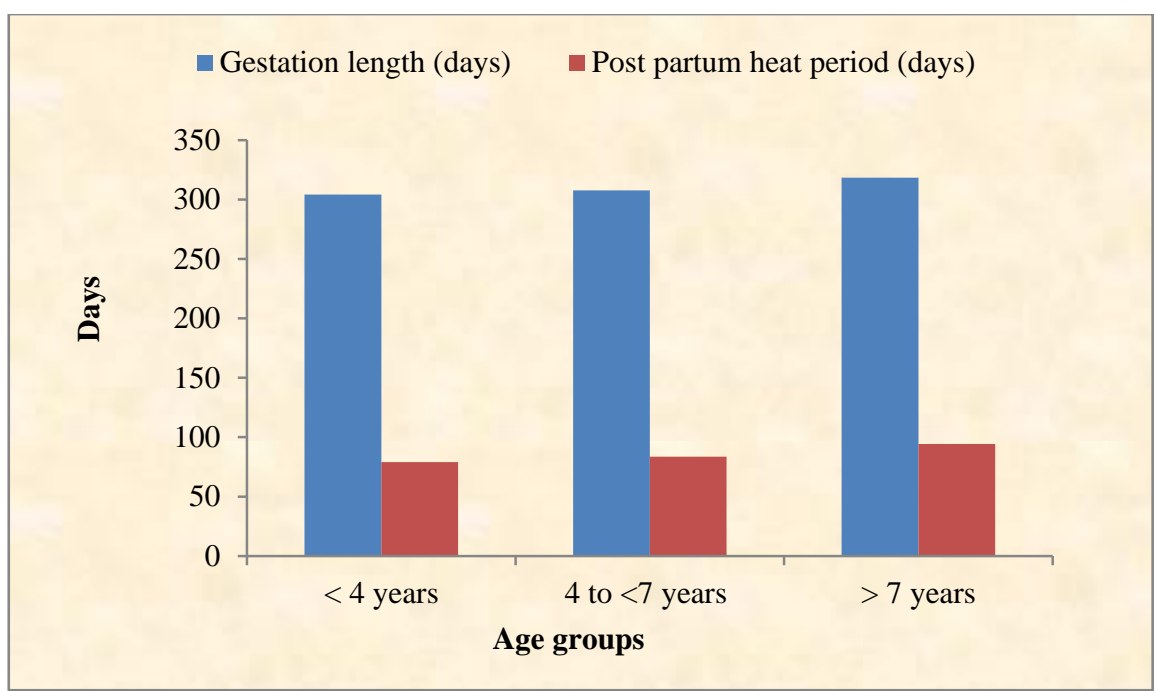

Figure 3. Effects of age groups on gestation length and postpartum heat period in buffalo cows.

\subsection{Effects of parity on reproductive and productive performance of buffalo cows}

To determine the variation of reproductive and productive parameters of buffalo cows due to parity effects are shown in Table 3 and Figure 4. The lower value of almost reproductive traits of age at puberty, age at first calving, gestation length, post partum heat period, birth weight of calf and calving interval (24.09 \pm 3.39 , $34.46 \pm 3.47,305.71 \pm 8.79,80.14 \pm 24.52,27.05 \pm 2.81$ and $360.29 \pm 21.38$ ) were found in $1^{\text {st }}$ calving and the higher values of $(25.53 \pm 4.77,35.80 \pm 4.94,314.84 \pm 16.87,85.75 \pm 25.26,29.50 \pm 4.03$ and $364.07 \pm 34.57)$ were found in $>3^{\text {rd }}$ calving. The lower values of milk yield per day and lactation length $(3.48 \pm 0.52$ and $200.45 \pm 34.90)$ were found in $3^{\text {rd }}$ calving and the higher values $(3.72 \pm 0.51$ and $207.69 \pm 31.31)$ were found in $1^{\text {st }}$ calving. Parity had significant $(\mathrm{P}<0.05)$ effect on gestation length, milk yield per day, birth weight of calf and had no significant $(\mathrm{P}>0.05)$ effect on age of puberty, age of first calving, post partum heat period, lactation length and calving interval. 
Table 3. Effects of parity on reproductive and productive performance of buffalo cows.

\begin{tabular}{|l|l|l|l|l|}
\hline \multirow{2}{*}{$\begin{array}{l}\text { Reproductive and productive } \\
\text { performances }\end{array}$} & \multicolumn{3}{|c|}{ Parity } & Average Value \\
\cline { 2 - 4 } & $\mathbf{1}^{\text {st }}$ Calving & $\mathbf{2}^{\text {nd }}$ Calving & $\mathbf{3}^{\text {rd }}$ Calving & \\
\hline Age at puberty (m) & $24.09 \pm 3.39$ & $25.12 \pm 2.83$ & $25.53 \pm 4.77$ & $25.05 \pm 4.00$ \\
& $\mathrm{~N}=52$ & $\mathrm{~N}=93$ & $\mathrm{~N}=5$ & $\mathrm{~N}=200$ \\
\hline Age at first calving (m) & $34.46 \pm 3.47$ & $35.09 \pm 3.00$ & $35.80 \pm 4.94$ & $35.26 \pm 4.14$ \\
& $\mathrm{~N}=52$ & $\mathrm{~N}=93$ & $\mathrm{~N}=55$ & $\mathrm{~N}=200$ \\
\hline Gestation length (days) & $305.71 \pm 8.79^{\mathrm{b}}$ & $305.92 \pm 10.05^{\mathrm{b}}$ & $314.84 \pm 16.87^{\mathrm{a}}$ & $308.28 \pm 10.92$ \\
& $\mathrm{~N}=52$ & $\mathrm{~N}=93$ & $\mathrm{~N}=55$ & $\mathrm{~N}=200$ \\
\hline Post partum heat period (days) & $80.14 \pm 24.52$ & $84.54 \pm 28.37$ & $85.75 \pm 25.26$ & $84.00 \pm 25.95$ \\
& $\mathrm{~N}=52$ & $\mathrm{~N}=93$ & $\mathrm{~N}=55$ & $\mathrm{~N}=200$ \\
\hline Milk yield per day (litre) & $3.72 \pm 0.51^{\mathrm{a}}$ & $3.58 \pm 0.59^{\mathrm{ab}}$ & $3.48 \pm 0.52^{\mathrm{b}}$ & $3.59 \pm 0.56$ \\
& $\mathrm{~N}=52$ & $\mathrm{~N}=93$ & $\mathrm{~N}=55$ & $\mathrm{~N}=200$ \\
\hline Lactation length (days) & $207.69 \pm 31.31$ & $202.00 \pm 33.34$ & $200.45 \pm 34.90$ & $202.76 \pm 33.54 \mathrm{~N}=$ \\
& $\mathrm{N}=52$ & $\mathrm{~N}=93$ & $\mathrm{~N}=55$ & 200 \\
\hline Birth weight of calf (kg) & $27.05 \pm 2.81^{\mathrm{b}}$ & $29.34 \pm 4.74^{\mathrm{a}}$ & $29.50 \pm 4.03^{\mathrm{a}}$ & $28.79 \pm 4.23$ \\
& $\mathrm{~N}=52$ & $\mathrm{~N}=93$ & $\mathrm{~N}=55$ & $\mathrm{~N}=200$ \\
\hline Calving interval (days) & $460.29 \pm 21.38$ & $460.42 \pm 27.89$ & $464.07 \pm 34.57$ & $461.36 \pm 20.41$ \\
& $\mathrm{~N}=52$ & $\mathrm{~N}=93$ & $\mathrm{~N}=55$ & $\mathrm{~N}=200$ \\
\hline
\end{tabular}

$\mathrm{m}=$ months, $\mathrm{kg}=$ kilogram, superscripts $(\mathrm{a}, \mathrm{b})$ in the same column differs significantly with each other $(\mathrm{p}<0.05)$.

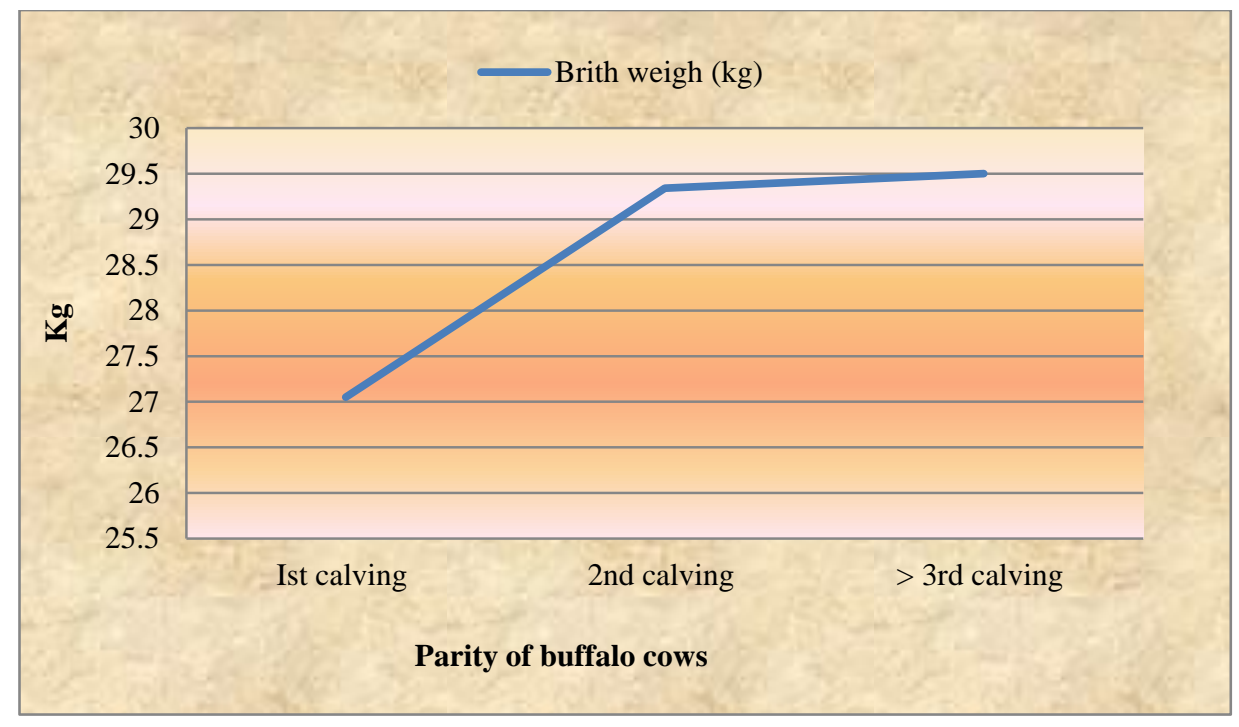

Figure 4. Effects of parity of buffalo cows on birth weight of calf.

\subsection{Effects of body weight on reproductive and productive performance of buffalo cows}

The effects of body weight on reproductive and productive performances of buffalo cows are furnished in Table

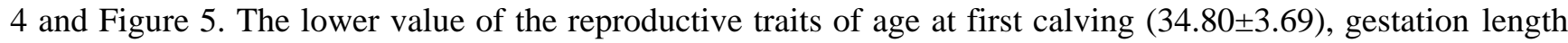
(305.86 \pm 9.35$)$, post partum heat period $(81.93 \pm 24.26)$, milk yield per day (3.45 \pm 0.43$)$, lactation length (201.93 \pm 33.51$)$, birth weight of calf $(25.09 \pm 2.31)$ and calving interval $(460.54 \pm 25.79)$ were found in $<250 \mathrm{~kg}$ and the higher value of almost reproductive traits of age at first calving (36.70 \pm 6.60$)$, gestation length

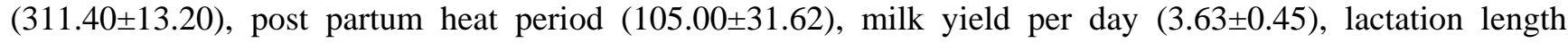
(216.00 \pm 39.77$)$, birth weight of calf $(34.00 \pm 2.10)$ and calving interval $(463.50 \pm 24.15)$ were found in $>350 \mathrm{~kg}$ body weight of buffalo cows except age at puberty which lower value $(24.69 \pm 3.38)$ were found in $250-350 \mathrm{~kg}$ of body weight and its higher value $(26.40 \pm 7.05)$ were found in $<250 \mathrm{~kg}$ body weight. Body weight had significant $(\mathrm{P}<0.05)$ effect on post partum heat period, birth weight of calf and had no significant $(\mathrm{P}>0.05)$ effect on other traits. 
Table 4. Effects of body weight on reproductive and productive performance of buffalos cows.

\begin{tabular}{|l|l|l|l|l|}
\hline \multirow{2}{*}{$\begin{array}{l}\text { Reproductive and Productive } \\
\text { performances }\end{array}$} & \multicolumn{3}{|c|}{ Body weight } & Average Value \\
\cline { 2 - 5 } & $<\mathbf{2 5 0} \mathbf{~ k g}$ & $\mathbf{2 5 0} \mathbf{3 5 0} \mathbf{~ k g s}$ & $\mathbf{3 5 0} \mathbf{~ k g}$ & \\
\hline Age at puberty (m) & $26.40 \pm 7.05$ & $24.69 \pm 3.38$ & $25.55 \pm 4.48$ & $25.05 \pm 4.00$ \\
& $\mathrm{~N}=63$ & $\mathrm{~N}=127$ & $\mathrm{~N}=10$ & $\mathrm{~N}=200$ \\
\hline Age at first calving (m) & $34.80 \pm 3.69$ & $35.95 \pm 4.44$ & $36.70 \pm 6.60$ & $35.26 \pm 4.14$ \\
& $\mathrm{~N}=63$ & $\mathrm{~N}=127$ & $\mathrm{~N}=10$ & $\mathrm{~N}=200$ \\
\hline Gestation length (days) & $305.86 \pm 9.35$ & $309.23 \pm 13.60$ & $311.40 \pm 13.20$ & $308.28 \pm 12.46$ \\
& $\mathrm{~N}=63$ & $\mathrm{~N}=127$ & $\mathrm{~N}=10$ & $\mathrm{~N}=200$ \\
\hline Post partum heat period (days) & $81.93 \pm 24.26^{\mathrm{b}}$ & $83.34 \pm 25.78^{\mathrm{b}}$ & $105.00 \pm 31.62^{\mathrm{a}}$ & $84.00 \pm 25.95$ \\
& $\mathrm{~N}=63$ & $\mathrm{~N}=127$ & $\mathrm{~N}=10$ & $\mathrm{~N}=200$ \\
\hline Milk yield per day (litre) & $3.45 \pm 0.43$ & $3.58 \pm 0.61$ & $3.63 \pm 0.45$ & $3.59 \pm 0.56$ \\
& $\mathrm{~N}=63$ & $\mathrm{~N}=127$ & $\mathrm{~N}=10$ & $\mathrm{~N}=200$ \\
\hline Lactation length (days) & $201.93 \pm 33.51$ & $202.33 \pm 32.70$ & $216.00 \pm 39.77$ & $202.76 \pm 33.54$ \\
& $\mathrm{~N}=63$ & $\mathrm{~N}=127$ & $\mathrm{~N}=10$ & $\mathrm{~N}=200$ \\
\hline Birth weight of calf (kg) & $25.09 \pm 2.31^{\mathrm{c}}$ & $30.22 \pm 3.78^{\mathrm{b}}$ & $34.00 \pm 2.10^{\mathrm{a}}$ & $28.79 \pm 4.23$ \\
& $\mathrm{~N}=63$ & $\mathrm{~N}=127$ & $\mathrm{~N}=10$ & $\mathrm{~N}=200$ \\
\hline Calving interval (days) & $460.54 \pm 25.79$ & $461.61 \pm 18.16$ & $463.50 \pm 24.15$ & $461.36 \pm 20.41$ \\
& $\mathrm{~N}=63$ & $\mathrm{~N}=127$ & $\mathrm{~N}=10$ & $\mathrm{~N}=200$ \\
\hline
\end{tabular}

$\mathrm{m}=$ months, $\mathrm{kg}=\mathrm{kilogram}$, superscripts $(\mathrm{a}, \mathrm{b}, \mathrm{c})$ in the same column differs significantly with each other $(\mathrm{p}<0.05)$.

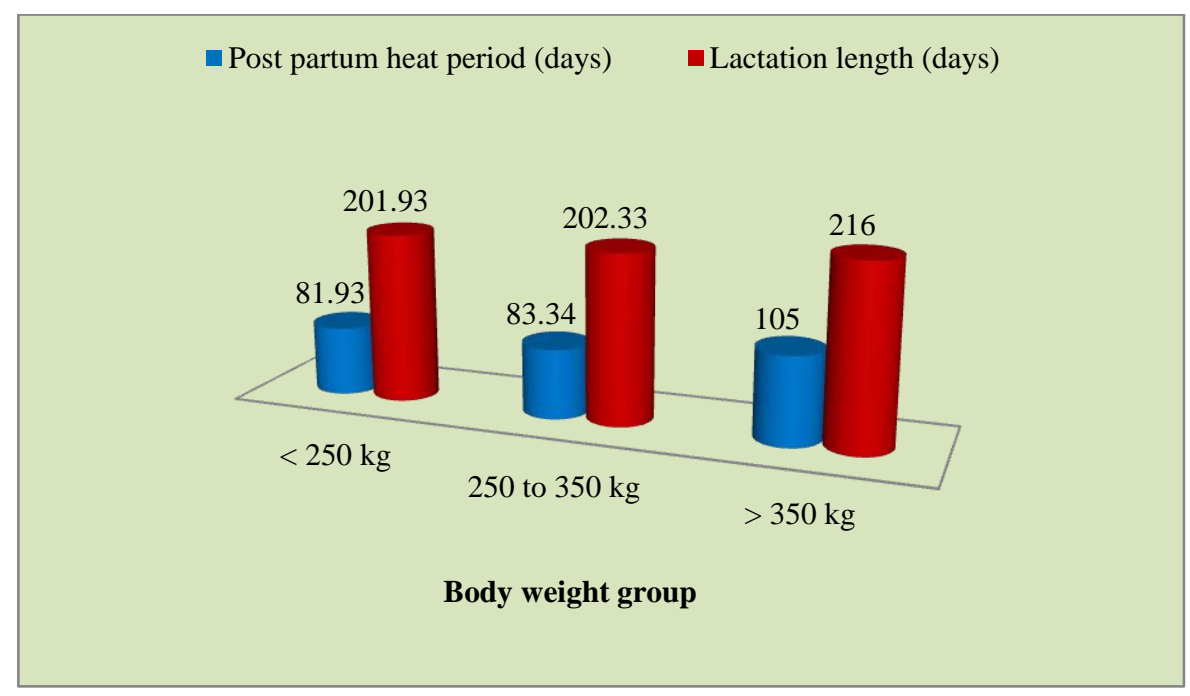

Figure 5. Effects of body weight on postpartum heat period and lactation length in buffalo cows.

\subsection{Effects of body condition on reproductive and productive performance of buffalo cows}

The effects of body condition score on reproductive and productive performance of buffalo cows are presented in Table 5 and Figure 6. Effects of good body condition resulted the lower value of reproductive traits of age at

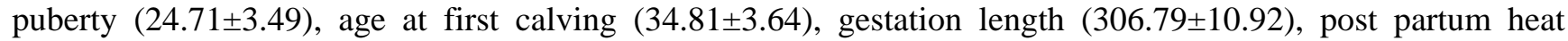

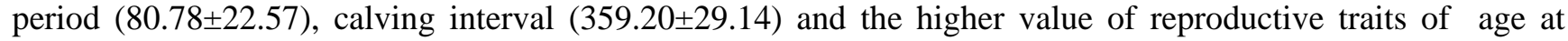

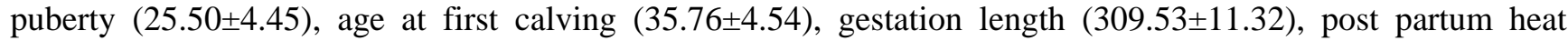
period (84.86 \pm 27.46$)$, calving interval $(363.91 \pm 6.18)$ were found in poor body condition of buffalo cows except milk yield per day, lactation length and birth weight of calf which lower value $(3.49 \pm 0.50,197.03 \pm 34.23$, $25.59 \pm 3.32$ ) were found in poor body condition and the higher value $(3.73 \pm 0.64,204.00 \pm 33.07,29.83 \pm 3.68)$ were found in good body condition of buffalo cows. Body condition score had significant $(\mathrm{P}<0.05)$ effect on milk yield per day, birth weight of calf and had no significant $(\mathrm{P}>0.05)$ effects on other reproductive traits. 
Table 5. Effects of body condition on reproductive and productive performance of buffalo cows.

\begin{tabular}{|l|l|l|l|l|}
\hline \multirow{2}{*}{$\begin{array}{l}\text { Reproductive and Productive } \\
\text { performances }\end{array}$} & \multicolumn{3}{|c|}{ Body condition } & Average Value \\
\cline { 2 - 4 } & Poor & Medium & Very good & \\
\hline Age at puberty (m) & $25.50 \pm 4.45$ & $25.00 \pm 4.36$ & $24.71 \pm 3.49$ & $25.05 \pm 4.00$ \\
& $\mathrm{~N}=32$ & $\mathrm{~N}=95$ & $\mathrm{~N}=73$ & $\mathrm{~N}=200$ \\
\hline Age at first calving (m) & $35.76 \pm 4.54$ & $35.43 \pm 4.53$ & $34.81 \pm 3.64$ & $35.26 \pm 4.14$ \\
& $\mathrm{~N}=32$ & 95 & $\mathrm{~N}=73$ & $\mathrm{~N}=200$ \\
\hline Gestation length (days) & $309.53 \pm 11.32$ & $308.99 \pm 13.87$ & $306.79 \pm 10.92$ & $308.28 \pm 12.46$ \\
& $\mathrm{~N}=32$ & $\mathrm{~N}=95$ & $\mathrm{~N}=73$ & $\mathrm{~N}=200$ \\
\hline Post partum heat period (days) & $84.86 \pm 27.46$ & $84.29 \pm 25.52$ & $80.78 \pm 22.57$ & $84.00 \pm 25.95$ \\
& $\mathrm{~N}=32$ & $\mathrm{~N}=95$ & $\mathrm{~N}=73$ & $\mathrm{~N}=200$ \\
\hline Milk yield per day (litre) & $3.49 \pm 0.50^{\mathrm{b}}$ & $3.58 \pm 0.42^{\mathrm{ab}}$ & $3.73 \pm 0.64^{\mathrm{a}}$ & $3.59 \pm 0.56$ \\
& $\mathrm{~N}=32$ & $\mathrm{~N}=95$ & $\mathrm{~N}=73$ & $\mathrm{~N}=200$ \\
\hline Lactation length (days) & $197.03 \pm 34.23$ & $203.74 \pm 33.82$ & $204.00 \pm 33.07$ & $202.76 \pm 33.54$ \\
& $\mathrm{~N}=32$ & $\mathrm{~N}=95$ & $\mathrm{~N}=73$ & $\mathrm{~N}=200$ \\
\hline Birth weight of calf (kg) & $25.59 \pm 3.32^{\mathrm{b}}$ & $28.84 \pm 4.59^{\mathrm{a}}$ & $29.83 \pm 3.68^{\mathrm{a}}$ & $28.79 \pm 4.23$ \\
& $\mathrm{~N}=32$ & $\mathrm{~N}=95$ & $\mathrm{~N}=73$ & $\mathrm{~N}=200$ \\
\hline Calving interval (days) & $463.91 \pm 6.18$ & $463.07 \pm 38.56$ & $459.20 \pm 29.14$ & $461.36 \pm 20.41$ \\
& $\mathrm{~N}=32$ & $\mathrm{~N}=95$ & $\mathrm{~N}=73$ & $\mathrm{~N}=200$ \\
\hline
\end{tabular}

$\mathrm{m}=$ months, $\mathrm{kg}=$ kilogram, superscripts $(\mathrm{a}, \mathrm{b})$ in the same column differs significantly with each other $(\mathrm{p}<0.05)$.

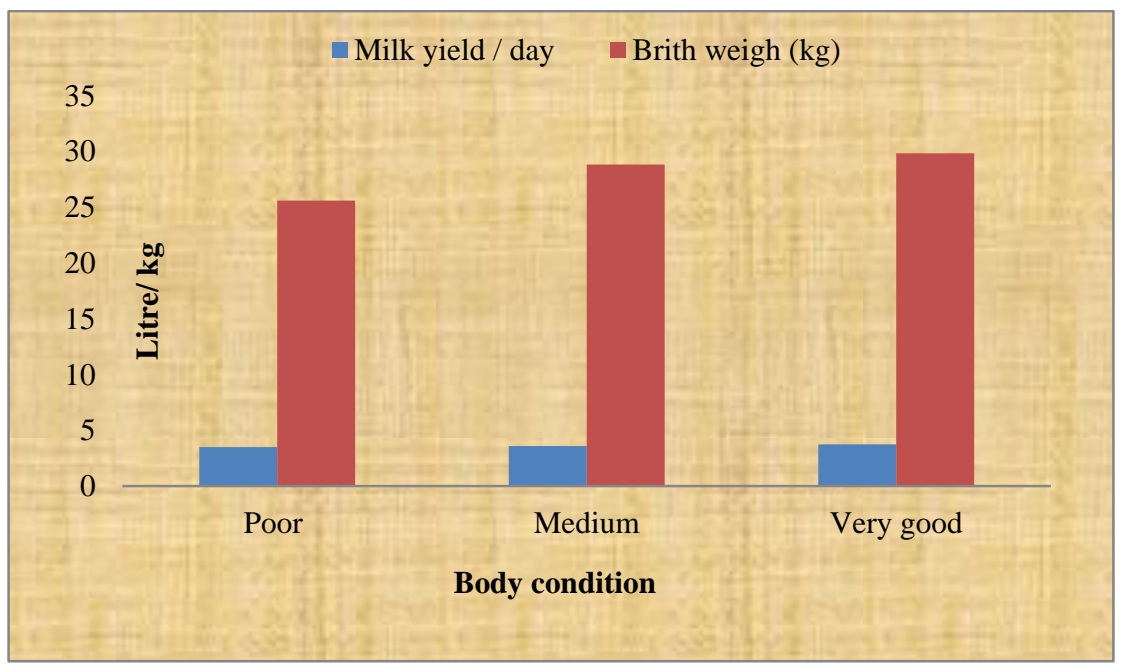

Figure 6. Effects of body condition on milk yield per day and birth weight of calf in buffalo cows.

\section{Discussion}

\subsection{The reproductive performance of buffalo cows in Rajshahi district of Bangladesh}

Problems that create from infertility are usually overlooked by the farmers, imbalance and undernourished feed management of dairy and buffalo cows and their calves, unavailability of pasture land, inadequate veterinary services and unawareness of farmers in herd health management are the burning issues, which seriously affects the farm economy in Bangladesh (Shamsuddin et al., 2001). In the present study, we found significant $(\mathrm{p}<0.05)$ difference on gestation length and post partum heat period of reproductive traits of Rajshahi district. Cuong (1983) concluded that age of puberty of local Murrah and their crosses buffalo in Vietnam were 36, 30, 34 months. The present study shown that the average age at puberty of buffalo cows were $25.05 \pm 4.00$ months, which is lower than the other study. The result is quit difference due to breed of buffalo, feed quality, environmental and managemental practices as well as data error.

Shah et al. (1987) mentioned that the average age at first calving of rural Nili-Ravi buffalo was $45.84 \pm 0.19$ months in Punjab. The average age at first calving reported by Bhalaru and Dhillon (1987) was about 42.36 months in Nili-Ravi buffaloes. Gupta et al. (1994) and Boro et al. (2020) found that age at first calving for Murrah buffaloes were 45.8 months and 43.69 \pm 0.46 months, respectively. Singh and Dhillon (1975) reported the average age at first calving of Murrah buffalo in India was $42.88 \pm 0.24$ months. On the other hand Cuong (1983) mentioned the age at first calving for Local, Murrah and their crosses in Vietnam were 48-54, 36-42 and 
42-48 months, respectively. This study shown that the average age at first calving was $35.26 \pm 4.14$ months, which is very earlier than other authors. Joshi et al. (1968) found the average gestation length of Indian buffaloes was $308.1 \pm 9.6$ days. The gestation period in farm bred and purchased buffaloes in India was found $314.02 \pm 1.53$ and $308.53 \pm 1.83$ days by Singh et al. (1973). The gestation period of Nili-Ravi was found 308.7 \pm 0.4 days in Pakistan by Usmani and Atahar (1997). Khan (1995) mentioned the average gestation period for Nili-Ravi and crossbred buffalo cows were $302.67 \pm 1.90$ and $300.67 \pm 3.55$ days, respectively. The present study shown that the average gestation length of buffalo cows was $308.28 \pm 12.46$ days which is very close to other authors. El-Sheikh and Mohamed (1967) found the post partum service interval of $1^{\text {st }}, 2^{\text {nd }}$ and $3^{\text {rd }}$ calving for Egyptian buffalo were 192.95, 152.9 and 317.0 days, respectively. Liu et al. (1985) reported the post partum heat period for triple cross-bred, Nili-Ravi, Murrah and Indigenous were 70.0 $17.8,127.9 \pm 107.2,94.7 \pm 82.7$ and 169 days, respectively. Unar et al. (1987) mentioned the first post partum estrus of Nili-Ravi buffalo ranged from 56.4 \pm 1.9 to $124.2 \pm 4.5$ days. On the other hand, Pervez et al. (1994) found the post partum heat interval averaged $171.79 \pm 4.01$ days. So the findings of present study were more or less similar to the findings of various authors as mentioned above. Hadi (1965) found that calving interval of Marathwada buffalo was $429.9 \pm 7.4$ days. El-Sheikh and Mohamed (1967) mentioned first calving interval of Egyptian buffalo was 484.74 2.86 days. Gurnani et al. (1976) reported the calving interval for Murrah buffalo averaged $434 \pm 6$ days. On the other hand Parera et al. (1987) found the average calving interval for indigenous buffalo of Srilanka was 329 to 416 days (mean 384.9 \pm 62.9 ). Shah et al. (1987) and Bhalaru and Dhillon (1987) showed calving interval for NiliRavi buffalo were $15.77 \pm 0.09$ months (about 474 days) and $497.7 \pm 8.7$ days, respectively. Boro et al. (2020) reported calving interval for Murrah buffalo was $15.5 \pm 4.51$ months. Khan et al. (1990) reported the average length of calving interval for Nili-Ravi buffalo in Pakistan was 552.44 \pm 18.4 days. The average calving interval obtained by Patel and Tripathi (1998) for Surti Buffalo in Gujarat was $556 \pm 11.9$ days. So the findings of present study, the average calving interval of buffalo cows were $461.36 \pm 20.41$ days which is more or less similar to other author. The results are quit difference due to breed of buffalo, better overall management, environment, high quality feed supply, available of veterinary services and awareness program of farmers etc.

\subsection{The productive performance of buffalo cows in Rajshahi district}

Productive performance is determined to a great extent by the milk yield at first lactation and the farm, followed by the age at first calving (Ilieva and Peeva, 2007). The success of any dairy farm depends upon efficient productive and reproductive performances of a dairy animal. Different genetic and non-genetic factors influence its performance potential (Boro et al., 2020). Arjava and Basu(1985), Bhalaru and Dhillon (1987), Huang and Runpei (1987), Singh et al. (1987), Vhat and Singh (1988) and Khan and Akhtar (1999) observed the average lactation yield for Nili-Ravi buffalo cows were 1847.98 $\pm 41.47,1641.1 \pm 32.1,1959,1701.13 \pm 51.836$, $1710,2076 \pm 843$ and $2020.04 \pm 44.59 \mathrm{~kg}$, respectively. Boro et al. (2020) reported that the milk yield per day and the average lactation yield for Murrah buffalo were $8.87 \pm 0.05 \mathrm{~kg}$ and $2147.6 \pm 87.06 \mathrm{~kg}$, respectively. Das and Patro (1988) reported the average milk yield of Kalahandi buffalo breed in India which ranged from 1-4 litre per day. On the other hand Faruque (1994) found the average milk yield for indigenous buffalo in Mymensingh was $2.12 \pm 0.34$ litre per day. The present study observed that the average milk yield per day was as $3.59 \pm 0.56$ litre which is more or less similar to other author. The variation of milk yield may be due to breed, feed and fodder availability and other management practices etc.

Arjava and Basu (1985) founded the average first lactation length for Nili buffalo cows was $308.83 \pm 3.46$ days. Singh et al. (1987) observed the first lactation mean for Nili Ravi buffalo cows was 355.939 days. On the other hand Acharya (1988) showed the average lactation length of river buffalo in India ranged 276-324 days. Tripathy et al. (1988) and Boro et al. (2020) reported the average lactation length for Murrah buffalo were $307.66 \pm 8.28$ and $297.8 \pm 1.9$ days, respectively. The findings of present study, the average lactation length of buffalo cows were $202.76 \pm 33.54$ days which is lower than the above findings.

Faruque and Amin (1994) mentioned that the average birth weight of indigenous buffalo calf of the coastal areas of Bangladesh was $22.00 \pm 3.50 \mathrm{~kg}$. On the other hand Hussen (1990) reported the average birth weight of buffalo calf in Tangail district was $26.74 \pm 2.4 \mathrm{~kg}$. Faruque (1994) observed the birth weight of indigenous buffalo calf in Mymensingh district was $24.75 \pm 2.12 \mathrm{~kg}$. In the present study the average birth weight of calf was $28.79 \pm 4.23 \mathrm{~kg}$ which is more or less similar to the findings of above authors. Bangso and Mahadevan (1989) and Boro et al. (2020) reported that the birth weight of Murrah calf were as $33.7 \pm 0.83$ and $34.76 \pm 0.54 \mathrm{~kg}$, respectively. Bhat and Singh (1988) mentioned that the birth weight of Murrah and Nili-Ravi breed ranged from 27-41 kg. On the other hand Khan (1995) reported that the average birth weight of Nili-Ravi and cross-bred calves were as $32.76 \pm 0.80$ and $28.50 \pm 0.79 \mathrm{~kg}$, respectively. These findings might be higher than the present study. The higher birth weight of calves might be due to consideration of Nili-Ravi and their cross-bred 
progeny. Therefore, training and awareness creation and available of veterinary services should be given to the farmers to increase the reproductive and/or productive performances of the buffalo cows and livelihood of the farmers through improved management practices.

\section{Conclusions}

The current investigation showed a relatively lower productive and reproductive performance of buffalo cows in Rajshahi district of Bangladesh. It depends on many factors such as managemental practices adopted, age, sires used for breeding, parity, environmental conditions and variations in feed and fodder availability etc. It could be concluded that the owners of buffalo of the Rajshahi areas of Bangladesh do not rear their buffalo in a scientific way rather than following traditional ways. It is therefore, necessary to give emphasis on improvement in the husbandry practices. It is needed to improve the productive and reproductive performance of Indigenous buffalo cows in order to gain more profit from buffalo rearing. Further work is suggested to collect more information regarding this line. Although it is difficult to come on a clear cut conclusion but data collected in this experiment will be helpful for future research and also gives a base line for buffalo development in Bangladesh.

\section{Acknowledgements}

The author is very much grateful to buffalo cows owners/farmers/attendant at Rajshahi City Corporation area for providing information during study period.

\section{Conflict of interests}

None to declare.

\section{References}

Arjava S and SB Basu, 1985. Genetic architecture of Nili-Ravi buffaloes. Ind. J. Anim. Sci., 55: 1046-1049.

Acharya MRA, 1988. The buffalo, dairy, drought and meat animal of Asia. Proc. II world buffalo Conference, Newdelhi., 2: 3-20.

Bangso TA and P Mahadevan, 1989. The present status and future of cross-breeding of water buffaloes in Asia. Symposiums on Buffalo Genotypes for small farms in Asia University, Pertanian Malaysia., 1084-90.

Bashir MK, MS Khan, SA Bhatti and A Iqbal, 2007. Lifetime performance of Nili-Ravi buffaloes in Pakistan. Asian J. Anim. Sci., 20: 661-668.

Boro P, J Saharia, D Bharali, M Sarma, M Sonowal and J Brahma, 2020. Productive and reproductive performances of Murrah buffalo cows: A review. J. Entomol. Zool. Stud., 8: 290-293.

Bhalaru SS and JS Dhillon, 1987. Performance of Nili-Ravi buffaloes. Punjab Agricultural University, Department of Animal Science, Ludhiana. Pakistan., 24: 27-29.

Cockril WR, 1974. The husbandry and health of domestic buffalo. Food and Agricultal Organization, Rome, Italy.

Coung LX, 1983. Perlbrrnance of Viethamese swamp buffaloes. Buffalo Bulletin, 2: 12-13.

Das K and BN Patro, 1988. Kalahandi buffalo breed of orissa. Buffalo Bulletin, 7: 35-38.

EI-Kirabi E, 1995. Buffalo population and production in Egypt. Buffalo Newsletter, 3: 8.

EI-Sheikh AS and AA Mohammed, 1967. The reproductive performance of the Egyptian buffalo. J. Anim. Prod., 5: 99-117.

Faruque MO and MR Amin, 1994. Indigenous buffaloes in the coastal area of Bangladesh, part-I. Distribution pattern and phenotypes. Bd. J. TRNG. Devt., 7: 83-85.

Faruque MO and MR Amin, 1995. Indigenous buffaloes in the coastal area of Bangladesh: part-II. Productivity of indigenous buffalo in the south western coastal area. Bd. J. TRNG. Devt., 4: 138-140.

Faruque MO, 1994. The indigenous buffalo in the Mymensingh district of Bangladesh. Buff. J., 10: 91-100.

Faruque MO, MA Hasnath and NU Siddique, 1990. Present status of buffaloes and their productivity raised by the small farmers of Bangladesh. Asian-Australian J. Anim. Sci., 3: 287-292.

Food and Agriculture Organization, 2007. Production Yearbook, volume. 4.

FAO (Food and Agriculture organization), 2005. Livestock policy recommendation for the Government of Bangladesh Initial finding for discussion, Technical co-operation programme, FAO regional office for Asia and Pacific, Bangkok., 4-13.

FAO (Food and Agriculture organization), 2009. Livestock, food security and poverty reduction. http://www.fao.org/docrep/012/i0680e/i0680e03.pdf

Ghaffar A, MI Khan, MA Mirza and WH Pirzada, 1991. Effect of year and calving season on some traits of economic importance in Nili-Ravi buffaloes. Pak. J. Agric. Res., 12: 217. 
Gupta BD, SN Kaushik and RR Mishra, 1994. Study on reproduction efficiency parameters of Murrah buffaloes. Ind. J. Dairy Sci., 47: 257-264.

Gurnani M, R Negarchenkar, SK Gupta and A Singh, 1976. Seasonality of calving and its influence on economic character of Murrah buffaloes. Ind. J. Dairy Sci., 29: 173-177.

Hadi MA, 1965. A preliminary study of certain productive and reproductive characters of marathwada buffaloes of Maharashtra state. Ind. Vet. J., 42: 692-699.

Huang H and WU Runpei, 1987. Nili-Ravi buffalo in the South China. Buffalo Bulletin, 6: 83-88.

Hafez ES, 1993. Reproduction in farm anmals, $4^{\text {th }}$ ed. Lea and Febiger, Philadelphia, pp. 13-15.

Ilieva Y and T Peeva, 2007. Productive life in buffalo cows and effect of some factors on it. ITAL. J. Anim. Sci., 6: 375-377.

Joshi SC, SPS Tomar and RN Desai, 1968. Relative Importance of maternal and environmental influences on pregnancy in buffaloes on military farm in the North India. Ind. J. Dairy Sci., 21: 37-42.

Khan RN and S Akhtar, 1999. Production characteristics of Nili-Ravi buffaloes. Asian-Australian J. Anim. Sci., 12: 56-60.

Khan S, MS Qureshi, N Ahmad, M Amjed, FR Durrani and M Younas, 2008. Effect of Pregnancy on Lactation Milk Value in Dairy Buffaloes. Asian J. Anim. Sci., 21: 523- 531.

Khan SU, 1995. Genetic potential of buffaloes raised under farm condition in Bangladesh. M.S. thesis. Deptartment of Animal Breeding and Genetic, Bangladesh Agricultural University, Mymensingh.

Khan RN, M Amjed, FR Durrani and S Akhtar, 1990. Production characteristics of Nili-Ravi buffaloes. AsianAustralian J. Anim. Sci., 12: 56-60.

Liu CH, SH Chang and HP Huang, 1985. The Chinese indigenous buffaloes and its crossbreeding. Buff. J., 1: 918.

Nicholson MJ and MH Butterworth, 1986. A guide to condition scoring of Zebu cattle. International Livestock Center for Africa Ababa, Ethopia, pp. 29.

Parera BMAO, LNAD Silva, VY Kuruwita and AM Karunaratae, 1987. Post partum ovarian activity, uterine involution and fertility in indigenous buffaloes at a selected village location in Srilanka. Anim. Reprod. Sci., 14: $115-127$.

Patel AK and VN Tripathi, 1998. Effect of non genetic factors on economic traits of Surti buffalo. Ind. J. Anim. Sci., 68: 566-569.

Pervez A, MK Aftab, A Jaheer and SH Hayat, 1994. Inheritance or some reproductive traits in Nili-Ravi buffaloes. Buffalo Bulletin, 13: 13-17.

Rahman SMA, 1991. Single animal ploughing in Bangladesh. A bench mark survey research report. BLRI, Savar, Dhaka.

Rahman MM, Khan MSU, Samad MA and Rahman MH. 2004. Practical Animal and Poultry Hygiene and Management. 1st Edi. Brahmaputra Packaging. Mymensingh. pp. 29, 126.

Shamsuddin M, MMU Bhuiyan, TK Sikder, AH Sugulle, PK Chandra and MGS Alam, 2001. Constraints limiting the efficiency of artificial insemination of cattle in Bangladesh. Int. Atom. Erg. Agcy., 1220: 9-27.

Suhail SM, MS Qureshi, S Khan, Ihsanullah and FR Durrani, 2009. Inheritance of economic traits of dairy buffaloes in Pakistan, Sarhad J. Agric., 25: 87-93.

Singh G and JS Dhillon, 1975. Environmental and genetic factors affecting the age of $1^{\text {st }}$ calving and $1^{\text {st }}$ lactation yield of buffaloes. J. Res. Ludhiana, 12: 286-296.

Singh C, RV Sing and YP Sing, 1987. Effect of some non genetic factors on economic traits in Nili-Ravi buffaloes, Ind. J. Anim. Sci., 57: 891-894.

Singh G, VK Taneja, LD Bajpavi and PN Bhat, 1973. Studies in Murrah buffaloes. Gestation length. Ind. J. Anim. Prod., 4: 88-90.

SKR Shah, FA Mir and RHI Usmani, 1987. The performance of rural Nili-Ravi buffaloes (Bubalus bubalis) V. Gestation length. Ind. J. Anim. Prod., 4: 88-90.

Tripathi VN, KM Reddy, RS Chauhan and DK Sadana, 1988. Estimation of breeding of Murah bulls. Buffalo Bulletin, 7: 28-40.

Unar AM, J Dhanani, MU Samo, S Khanghrani and L Kaka, 1987. Effect of feeding different levels of ration, suckling post partum in Kundi buffaloes.

Usmani RH and IH Atahar, 1997. Reproductive function in Nili-Ravi buffaloes after short term treatment with recombinant bovine Somatotropin hormone. Asian-Australian J. Anim. Sci., 10: 229-232.

Vhat PN and A Shing, 1988. Genetic improvement of buffaloes, $2^{\text {nd }}$ World Buffalo Conference, New Delhi., 2: 323-256. 